\title{
PENYAJIAN LAPORAN KEUANGAN ENTITAS BERORIENTASI NONLABA MENGGUNAKAN MICROSOFT EXCELL DI YAYASAN CINTA TANAH AIR
}

\author{
MARGO SAPTOWINARKO PRASETYO*, LA ODE ABDUL WAHAB* dan ENDANG WULANDARI** \\ *Dosen Prodi Manajemen, STIE Port Numbay Jayapura \\ ** Dosen Prodi Akuntansi, Universitas Sahid
}

\begin{abstract}
Based on the results of the analysis described in the discussion chapter, it can be concluded as follows: The Microsoft Excel application can be used in the process of presenting the Financial Statements of Non-profit Oriented Entities at the Cinta Tanah Air Foundation. Some of the conveniences of using this application are, this application is generally available on every PC computer, and is easy to learn.
\end{abstract}

Keywords: Non Profit Financial Statements, Accounting, Balance Sheet

Abstrak: Berdasarkan hasil analisis yang telah diuraikan pada Bab pembahasan, maka dapat disimpulkan sebagai berikut: Aplikasi Microsoft Excell dapat digunakan dalam proses Penyajian Laporan Keuangan Entitas Berorientasi Nonlaba Di Yayasan Cinta Tanah Air. Beberapa kemudahan menggunakan aplikasi ini adalah, aplikasi ini ada umumnya ada tersedia di setiap PC computer, dan mudah dipelajari.

Kata Kunci : Laporan Keuanga Non Laba, Akuntansi, Neraca

\section{Pendahuluan}

Secara umum badan usaha yang ada di Indonesia dapat berbentuk Perorangan, Persekutuan, dan Perseroan Terbatas (Soetedjo, 2010). Ke semua badan usaha atau entitas tersebut dalam usahanya bertujuan mencari keuntungan atau laba.

Selain itu ada beberapa bentuk badan hukum yang tujuan utamanya tidak mencari keuntungan atau laba. Badan hukum tersebut dapat dikatakan sebagai entitas non laba. Jusup, sebagaimana dikutip Kaomaneng (2013), mendefinisikan organisasi nonlaba sebagai sebuah organisasi yang tidak bertujuan mencari laba misalnya organisasi keagamaan atau lembaga pendidikan. Organisasi tersebut juga membutuhkan informasi akuntansi seperti halnya organisasi yang bertujuan mencari laba. Walapun organisasi semacam ini tidak mencari laba, namun mereka tetap berurusan dengan keuangan.

Yayasan dan perkumpulan merupakan salah dua dari contoh bentuk entitas nonlaba. Namun Yayasan dalam konteks Indonesia merupakan entitas nonlaba yang lebih populer untuk menjalankan usaha-usaha yang bersifat nonlaba. Sekolah, perguruan tinggi, maupun lembaga swadaya masyarakat di Indonesia pada umumnya menggunakan bentuk Yayasan.

Sekalipun entitas nonlaba telah ada dalam kehidupan sehari-hari akan tetapi tidak banyak yang mengetahui bagaimana pelaporan keuangan sebuah entitas nonlaba.

Untuk menyajikan laporan keuangan yang sesuai dengan standard dan tepat waktu dan efisien, diperlukan alat bantu berupa aplikasi. Banyak aplikasi yang dapat kita pakai, misalnya; Accurate, Myob, GL, Microsoft Excel, atau juga pesan secara khusus. Jika kita menggunakan aplikasi pesanan, biasanya harganya mahal, dan ketika ada perubahan atau penyesuaian biasanya akan sulit dilakukan dan biayanya juga kadang cukup mahal dan kadang memakan waktu yang lama, misalnya perusahaan pembuat aplikasi berada jauh di luar daerah. Microsoft Exel adalah salah satu aplikasi yang sangat familiar bagi banyak orang, sehingga mudah digunakan oleh banyak orang disamping aplikasi ini umumnya ada di semua perangkat computer, sehingga jika laporan keuangan dibuat dengan aplikasi ini, 
maka laporan keuangan ini dapat dibaca di banyak perangkat tanpa harus menginstal secara khusus.

\section{Organisasi Nonlaba}

Sebuah organisasi nonlaba atau organisasi non profit adalah suatu organisasi yang bersasaran pokok untuk mendukung suatu isu atau untuk suatu tujuan yang tidak komersial, tanpa ada perhatian terhadap hal-hal yang bersifat mencari laba (moneter). Organisasi nonlaba meliputi keagamaan, sekolah/ pendidikan, derma publik, rumah sakit dan klinik publik, organisasi politis, bantuan masyarakat dalam hal perundang-undangan, organisasi sukarelawan, serikat buruh.

\section{Fungsi Informasi Akuntansi}

Fungsi utama akuntansi adalah sebagai informasi keuangan suatu organisasi. Dari laporan akuntansi kita bisa melihat posisi keuangan suatu organisasi beserta perubahan yang terjadi di dalamnya. Akuntansi dibuat secara kualitatif dengan satuan ukuran uang. Informasi mengenai keuangan sangat dibutuhkan khususnya oleh pihak manajer/ manajemen untuk membantu membuat keputusan suatu organisasi.

\section{Siklus Akuntansi}

Rangkaian langkah dimulai ketika transaksi terjadi dan diakhiri dengan penyertaannya dalam laporan keuangan. Catatan akuntansi tambahan mungkin akan digunakan selama siklus akuntansi terjadi, termasuk input catatan di buku besar dan neraca saldo.

\section{Komponen Laporan Keuangan Nonlaba}

Dalam PSAK No. 45 disebutkan bahwa "Laporan keuangan organisasi nonlaba meliputi laporan posisi keuangan pada akhir periode laporan, laporan aktivitas serta laporan arus kas untuk suatu periode pelaporan dan catatan atas laporan keuangan.”

\section{Microsoft Excel}

Pengertian Microsoft Excel adalah sebuah program atau aplikasi yang merupakan bagian dari paket instalasi Microsoft Office, berfungsi untuk mengolah angka menggunakan spreadsheet yang terdiri dari baris dan kolom untuk mengeksekusi perintah. Microsoft Excel telah menjadi software pengolah data/ angka terbaik di dunia, selain itu Microsoft Excel telah didistribusikan secara multi-platform. Microsoft Excel tidak hanya tersedia dalam platform Windows, Microsoft Excel juga tersedia di MacOS, Android dan Apple.

\section{STIE Port Numbay}

Sekolah Tinggi Ilmu Ekonomi Port Numbay yang dibuka pada tahun kuliah 1999/2000 sesuai Surat Keputusan Menteri Pendidikan dan Kebudayaan Republik Indonesia Nomor : 157/D/0/2000 tentang Pembukaan Sekolah Tinggi Ilmu Ekonomi Port Numbay Jayapura yang ditetapkan di Jakarta pada tanggal 18 Agustus 2000. Pada saat pendiriannya STIE Port Numbay terdiri dari 3 program studi yaitu Program Studi Keuangan dan Perbankan (D3), Program Studi Manajemen (S1), dan Program Studi Ekonomi Pembangunan (S1). Sedangkan pembukaan Program Studi Magister Manajemen (S2) berdasarkan SK Mendikbud RI No. 186/E/O/2013 tanggal 7 Mei 2013

\section{Penyajian Laporan Keuangan Menggunakan Aplikasi} Microsoft Excel

\section{Memasukan Data Daftar Akun (Chart Of Account)}

Berdasarkan laporan keuangan Yayasan Cinta Tanah tahun 2018 dan wawancara dengan personel di bagian Keuangan maka dapat disusun sebuah Daftar Akun.

\section{Memasukan Data Daftar Mahasiswa}

Berikut adalah contoh dari Daftar Mahasiswa yang aktif, yang diambil dari Simakad 
Tabel 4.2

Daftar Nama Mahasiswa

\begin{tabular}{|c|l|}
\hline \multicolumn{1}{|c|}{ NPM } & \multicolumn{1}{|c|}{ NAMA MAHASISWA } \\
\hline 123016344315040 & Erdis Wanimbo \\
\hline 143009344317094 & Silvester Maday \\
\hline 143009344319001 & Abdul Razzaq \\
\hline 143009344319002 & Alfonsson Jefri Edi Pigay \\
\hline 143009344319004 & Baki Taplo \\
\hline 143009344319006 & Covianan Nauw \\
\hline 143009344319007 & Deprince Wanimbo \\
\hline 143009344319009 & Derince Wonda \\
\hline
\end{tabular}

Sumber: Simakad STIE Port Numbay

\section{Memasukan Data Kertas Kerja Kas}

Pertama masukan tanggal transaksi Masukan

Kode rekening/ akun, maka nama akun akan otomatis muncul. Masukan no bukti transaksi (sesuai dengan Buku Kas), Masukan keterangan penerimaan atau pengeluaran kas. Masukan Jumlah Penerimaan kas pada Mutasi Debet, atau masukan pada sisi Kredit untuk pengeluaran Kas. Angka Saldo akan otomatis terisi/ berubah, demikian juga untuk Rekening (D/K) dan Total.

\section{Memasukan Data Kertas Kerja Bank}

Pertama masukan tanggal transaksi Masukan Kode rekening/ akun, maka nama akun akan otomatis muncul. Masukan no bukti transaksi (sesuai dengan Buku Bank), Masukan keterangan penerimaan atau pengeluaran kas. Masukan Jumlah Penerimaan kas pada Mutasi Debet, atau masukan pada sisi Kredit untuk pengeluaran Kas. Angka Saldo akan otomatis terisi/ berubah, demikian juga untuk Rekening (D/K) dan Total.

\section{Memasukan Data Kertas Kerja Buku Besar Pembantu} Piutang

Salah satu permasalahan krusial dalam pengelolaan Keuangan di Entitas yang bergerak pada sektor pendidikan adalah pengelolaan dari tagihan dari Siswa atau mahasiswa, oleh karena itu diperlukan informasi yang akurat berkaitan dengan piutang tersebut. Berikut adalah contoh dari Kertas kerja Buku Besar Pembantu Piutang. Pengisian untuk Kolom No, NPM, dan
Keterangan/ Nama sesuai dengan Daftar Mahasiswa. Yang perlu dilakukan adalah memasukan jumlah/ nilai Saldo awal Piutang. Misalkan semua mahasiwa adalah baru, maka angkanya adalah Nol semua. Untuk Kolom Mutasi akan otomatis terisi bila ada transaksi pada Kertas Kerja Adjustment Mahasiswa. Dan Nilai Saldo Akhir juga otomatis terisi.

\section{Memasukan Data Kertas Kerja Adjustment Mahasiswa} Dari Kertas kerja Adjustmen Mahasiswa. Dimana NPM dan Nama Mahasiswa diambil dari Daftar Mahasiswa dan selanjutnya perlu dimasukan data kewajiban yang timbul setiap mahasiswa pada awal semester. Tentunya setiap mahasiwa akan mempunyai kewajiban yang berbeda-beda.

\section{Memasukan Data Kertas Kerja Daftar Aset Tetap}

Data dari daftar aset tetap disalin dari daftar Aset tetap. Daftar aset tetap terdiri dari 3 katagori yaitu: Inventaris Kantor, Kendaraan, dan Gedung. Berikut adalah contoh dari Daftar aset tetap.

\section{Memasukan Data Kertas Kerja Adjustment.}

Setiap periode berakhir, perlu dilakukan penyesuaian/ adjustment beberapa akun. Yang selalu ada pada umumnya seperti posting beban depresiasi/ penyusustan aset tetap, dimana besaran angka-angka penyusutan diambil dari daftar aset tetap. 
JURNAL EKONOMI \& BISNIS

Sekolah Tinggi Ilmu Ekonomi Port Numbay Jayapura
p-ISSN : 2086-4515 | e-ISSN : 2746-1483

Volume 11, Nomor 2, Januari 2021

ejurnal.stie-portnumbay.ac.id

\section{Kertas Kerja Neraca Lajur}

Kertas Kerja Neraca Lajur akan otomatis terisi angka-angkanya pada semua bagian kecuali untuk nilai kenaikan aset neto, yang disesuaikan dengan selisih kolom debet dan kredit pada bagian Laporan Aktivitas. Perlu diperhatikan bahwa angka akun ayat silang di bagian Trial Balance, baik Debet maupun Kredit harus bernilai Nol, jika tidak artinya ada kesalahan.
Hal lain yang juga diperhatikan adalah harus diperhatikan bahwa Total nilai Debet harus sama dengan Total nilai Kredit

\section{Kertas Kerja Laporan Aktivitas}

Kertas Kerja Laporan Aktivitas akan otomatis terisi angka-angkanya pada semua bagian. Berikut adalah contoh dari Laporan Aktivitas.

Kertas Kerja Laporan Aktivitas

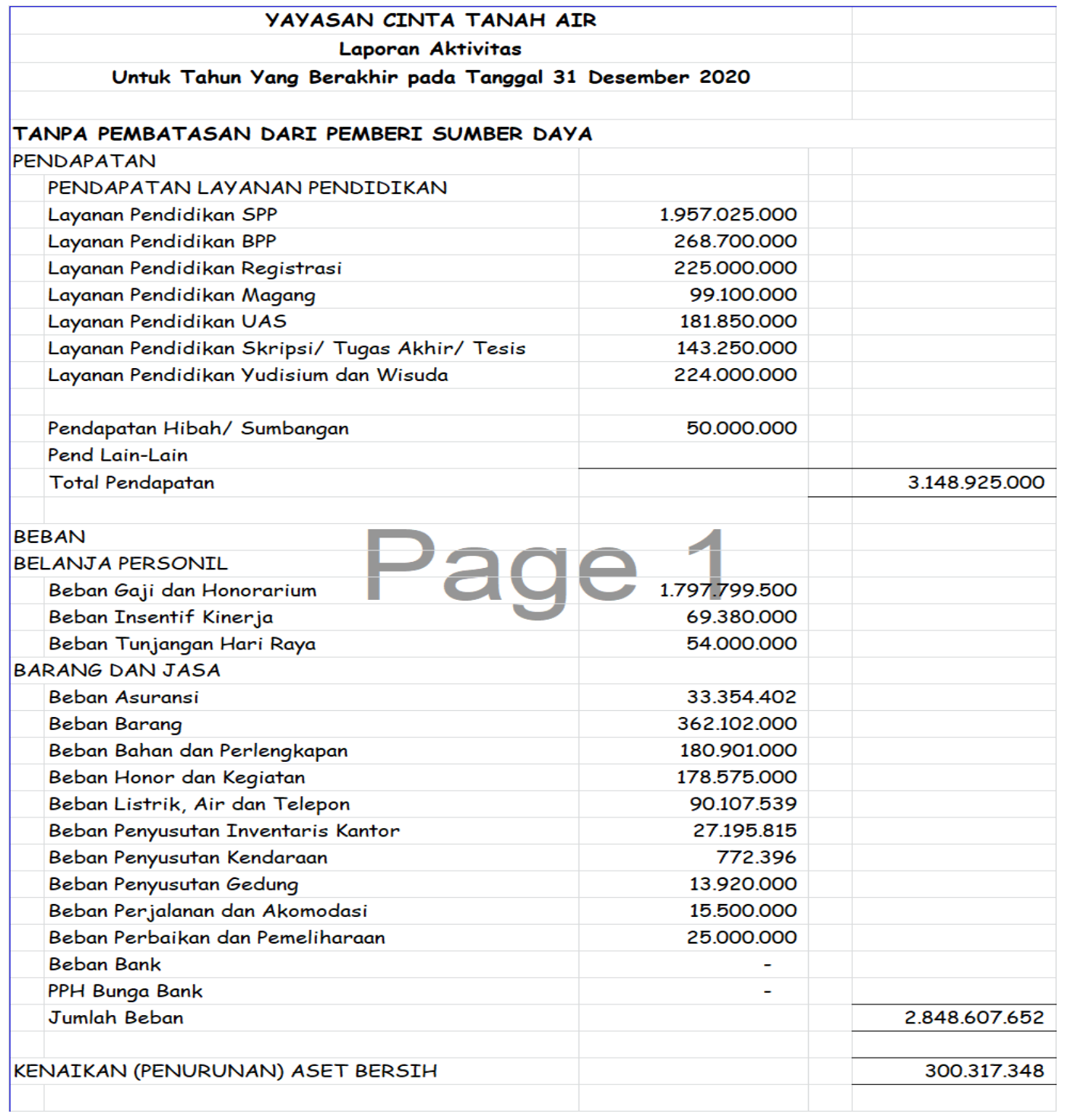

\section{Kertas Kerja Laporan Posisi Keuangan}

Kertas Kerja Laporan Posisi Keuangan akan otomatis terisi angka-angkanya pada semua bagian. Berikut adalah contoh dari Laporan Posisi Keuangan. 
Kertas Kerja Laporan Posisi Keuangan

\begin{tabular}{|c|c|}
\hline YAYASAN CINTA TANAH AIR & \\
\hline LAPORAN POSISI KEUANGAN & \\
\hline PER 31 DESEMBER 2020 & \\
\hline ASET & \\
\hline ASET LANCAR & \\
\hline Kas & 224.497 .000 \\
\hline Bank Bank Negara Indonesia (Persero)Tbk 1 & 795.346 .462 \\
\hline Bank Papua & 111.498 .264 \\
\hline Piutang SPP & 48.500 .000 \\
\hline Piutang BPP & 8.000 .000 \\
\hline Penyisihan Kerugian Piutang & $(8.750 .000)$ \\
\hline Piutang D & - \\
\hline Piutang $\mathrm{F}$ & - \\
\hline Piutang Lain-lain & - \\
\hline Biaya Dibayar Dimuka & - \\
\hline Persediaan Alat Tulis Kantor & 2.860 .000 \\
\hline Persediaan Bahan Habis Pakai Cleaning Servis & 395.000 \\
\hline Jumlah Aktiva Lancar & 1.182 .346 .726 \\
\hline & \\
\hline ASET TIDAK LANCAR & \\
\hline Tanah & 590.000 .000 \\
\hline Gedung dan Bangunan & 12.775 .000 .000 \\
\hline Akumulasi Penyusutan Gedung & $(3.001 .586 .667)$ \\
\hline Kendaraan & 895.290 .000 \\
\hline Akumulasi Penyusutan Kendaraan & $(533.461 .563)$ \\
\hline Inventaris Kantor & 1.895 .650 .000 \\
\hline Akumulasi Penyusutan Inventaris Kantor & $(536.819 .150)$ \\
\hline Aset Lainnya Buku Teks & 260.200 .000 \\
\hline Aset Lainnya Buku Jurnal Nasional Terakreditasi, Prosiding dan Jurnal Internasional & 10.000 .000 \\
\hline Jumlah Aset Tidak Lancar & 12.354 .272 .620 \\
\hline & \\
\hline JUMLAH ASET & 13.536 .619 .346 \\
\hline & \\
\hline LIABILITAS & \\
\hline LIABILITAS JANGKA PENDEK & \\
\hline Hutang Bank & - \\
\hline Beban Yang Masih Harus di Bayar LISA & 9.455 .570 \\
\hline Beban Yang Masih Harus di Bayar Gaji dan Honorarium & 285.350 .000 \\
\hline Hutang Lain-lain & - \\
\hline Jumlah Kewajiban Lancar & 294.805 .570 \\
\hline & \\
\hline LIABILITAS JANGKA PANJANG & - \\
\hline EKUITAS & \\
\hline Aset Bersih Awal & 12.941.496.428 \\
\hline Aset Bersih Penambahan & 300.317 .348 \\
\hline Jumlah Aset Neto & 13.241 .813 .776 \\
\hline & \\
\hline JUMLAH LIABILITAS DAN EKUITAS & 13.536 .619 .346 \\
\hline
\end{tabular}

\section{Kesimpulan}

Berdasarkan hasil analisis yang telah diuraikan pada Bab pembahasan, maka dapat disimpulkan sebagai berikut: Aplikasi Microsoft Excell dapat digunakan dalam proses Penyajian Laporan Keuangan Entitas Berorientasi Nonlaba Di Yayasan Cinta Tanah Air. Beberapa kemudahan menggunakan aplikasi ini adalah, aplikasi ini ada umumnya ada tersedia di setiap PC computer, dan mudah dipelajari.
Saran

Hal-hal yang dapat dilakukan guna peningkatan dan pembenahan adalah sebagai berikut:

1. Kiranya hasil penelitian ini dapat diterapkan pada entitas yang berorientasi Non Laba.

2. Kiranya hasil penelitian ini dapat dikembangkan pada entitas yang berorientasi laba. 
JURNAL EKONOMI \& BISNIS

Sekolah Tinggi Ilmu Ekonomi Port Numbay Jayapura
p-ISSN : 2086-4515 | e-ISSN : 2746-1483

Volume 11, Nomor 2, Januari 2021 ejurnal.stie-portnumbay.ac.id

\section{DAFTAR PUSTAKA}

Adityawarman, 2006. Evaluasi Penerapan PSAK No. 45 tentang Pelaporan Keuangan Organisasi Nirlaba dalam Laporan Keuangan Rumah Sakit Berstatus Badan Layanan Umum (Studi Kasus pada Rumah Sakit X di Jawa Tengah). Skripsi. Semarang: Fakultas Ekonomi. Universitas Diponegoro

Ahmad Syafi'i Syakur. 2009. Intermediate Accounting, Jakarta: AV Publisher

Allison. 2005. Perencanaan Strategis Bagi Organisasi Nirlaba, Jakarta: Yayasan Obor Indonesia

Anthony, Robert N.; Young, David M. 2003. Management Control in Nonprofit Organizations. Illinois: Richard D. Irwin Inc

Ardi Wira. 2013. file:///F:/ SKRIPSI REFRENSI/ karakteristik-dan-lingkungan-yayasan. html (Diakses tanggal 15 Juli 2014 : Pukul 13.15)

Bambang Supomo dan Nur Indriantoro, 1999. Metodologi Penelitian Bisnis untuk Akuntansi dan Manajemen. Yogyakarta: BPFE

Baridwan, Zaki. 2010. Sistem Akuntansi Penyusunan Prosedur dan Metode. Yogyakarta: BPFE

Bastian, Indra. 2007. Akuntansi Yayasan dan Lembaga Publik. Jakarta: Erlangga

Bungin, B. 2003. Analisis Data Penelitian Kualitatif. Jakarta: PT Raja Grafindo Persada

Dian Kurniasari. 2011. file:///F:/Sekilas tentang PSAK nomor45 Pelaporan Keuangan Organisasi Nirlaba Dian Kurniasari. html (Diakses tanggal 14 Juli 2014 : Pukul 11.35)

Harahap, Sofyan Syafri. 2011. Analisis Kritis Atas Laporan Keuangan, Jakarta: PT Raja Grafindo Persada

Ikatan Akuntansi Indonesia, 2007. Standar Akuntansi Keuangan. Jakarta: Salemba 4

Irene Septianita Kaomaneng. 2013. Penerapan Sistem Akuntansi dalam Pengelolaan Keuangan Gereja. Journal Uniera. Vol. 2. No. 1 Februari (1-10)
Jamiatul Laela. 2013. file:///F:/coretan kuliahku AKUNTABILITAS YAYASAN dan PENGENDALIAN KEUANGAN.htm (Diakses tanggal 14 Juli 2014 : Pukul 11.05)

J.Salusu. 2004. Pengambilan Keputusan Stratejik untuk Organisasi Publik dan Organisasi Non-Profit. Jakarta: Grasindo

Kaomaneng, I.S (2013), Penerapan Sistem Akuntansi Dalam Pengelolaan Keuangan Gereja. Skripsi dalam

https://d1wqtxts1xzle7.cloudfront.net/32900589/ju niera57-

Zkf1bQR3Gc3J71d2tfuUzlPVC.pdf?1391371928

=\&response-content-

disposition=inline $\% 3 \mathrm{~B}+$ filename $\% 3$ DPENERAP

AN_SISTEM_AKUNTANSI_DALAM_PENGEL O.pdf\&Expires $=1626312410 \&$ Signature $=X R m j Y i$ Qfm2JXiFk33bwtLLulhPyWv7yvIt14f-

mwZ1QL5CUOteRZPbFjk22Q-

CmC7HNjkwxHaDbZD4i3TvolJKGMGB9-

DcPudYvx02PY-

4ZkEnQ5jW0eLxL NQCXEAmPhQwKV3ud0Tt aPnL7mXVHDs9VTGmZfU2-w9w6vRbfR-Ovu-

Xwje8pXblUM2OD1O rYXZncwlTdhs6wmezsX sWmG xcxB7nGcwfS824QG3JmI0oeCT-

U26yddFdmy1fDD6mdZI3A1QscwhFu〜75G2jagOlK Eo6TztGNiKRSER6pAvfX2G5Lo fTYTRmqlbn3iocuBoQosft182bwNTrrIkQ \& \&e y-Pair-Id=APKAJLOHF5GGSLRBV4ZA.

Diakses pada tanggal 20 Desember 2020.

Melisa Mamesah. 2013. Penerapan Psak No.45 pada GMIM Efrata Sentrum Sonder Kaitannya dengan Kualitas Informasi Laporan Keuangan. Jurnal EMBA. Vol.1. No.4 Desember (1717-1728).

Pahala Nainggolan. 2005. Akuntansi Keuangan Yayasan dan Lembaga Nirlaba Sejenis. Jakarta: PT Raja Grafindo Persada

Pura Rahman. 2013. Pengantar Akuntansi 1, Pendekatan Siklus Akuntansi. Erlangga. Jakarta 
Resha Dwi Ayu P.M. 2014. Rekonstruksi Pelaporan Keuangan Organisasi Nirlaba Pada Yayasan Pendidikan Islam Indocakti Malang Berdasarkan PSAK Nomor 45. Skripsi. Jember: Fakultas Ekonomi. Universitas Jember

Ronny Hendrawan. 2011. Analisis Penerapan PSAK No. 45 Tentang Pelaporan Keuangan Organisasi Nirlaba Pada Rumah Sakit Berstatus Badan Layanan Umum (Studi Kasus Di RSUD Kota Semarang). Skripsi. Semarang: Fakultas Ekonomi. Universitas Diponegoro.

Soetedjo, Soegeng. 2010. Pengantar Akuntansi I, Proses Akuntansi Perusahaan Jasa. Airlangga University Press. Surabaya. 